\title{
Preparing Light Weight Concrete with Reinforced Fibers
}

\author{
Rami Joseph Aghajan Sldozian \\ Department of Applied Science, University of Technology. \\ E-mail: rami_j_ag@yahoo.com
}

\begin{abstract}
This paper is study to prepare the lightweight concrete by chemical way, and this is by adding (2\%) aluminum powder by the weight of cement to obtained bubbles inside the mix of concrete. Also replace fine aggregate by the hollow ceramic powder called (Cenosphere) by ratio $(25 \%, 50 \%$, $75 \%$ and $100 \%$ ) from the weight of fine aggregate. Adding glass fibers to concrete mix by ratio the $(1 \%, 1.5 \%$ and $2 \%)$ from the weight of cement, to enhance the mechanical properties of the samples. The results show increase in compressive and tensile strength by increase the ratio of cenosphere instead fine aggregate, and the best ratio was $(50 \%)$ and $(2 \%)$ aluminum, and the best ratio of fiber glass was $(1.5 \%)$. Generally, decrease the density of samples when increase the ratio of bubbles and the ratio of cenosphere instead the fine aggregate, the density was $(0.868 \mathrm{gm} / \mathrm{cm} 3)$ float on the water at ratio (100\% cenosphere). Decrease the thermal conductivity by increase the ratio of aluminum bubbles and the replacement of ceramic powder (cenosphere) instead fine aggregate. Observed also increase the high of samples from $(25.26 \mathrm{~mm})$ normal sample to $(57.51 \mathrm{~mm})$ for the sample contain $100 \%$ ceramic powder and $2 \%$ aluminum powder.
\end{abstract} [DOI: 10.22401/JNUS.20.1.07]

Keywords: Cement, concrete, Cenosphere, Thermal conductivity, Density.

\section{Introduction}

Concrete is a common construction material in Iraq. Normal concrete consists of coarse aggregate, fine aggregate and cement as a binding agent with water. There are special requirements for such low density concrete and thermal insulation, but must maintain the mechanical properties of concrete. The concrete which has a lower density than that made using gravel or crushed aggregate is named as lightweight concrete. The density of concrete can be reduced by replacing some of the solid materials in the mix by air voids $[3,4,5]$.

Lightweight Concrete can be defined as types of concrete that include an increase in the volume of concrete with a reduction in the weight of concrete. It is lighter than the normal concrete with a dry density of $300 \mathrm{~kg} / \mathrm{m}^{3}$ up to $1840 \mathrm{~kg} / \mathrm{m}^{3}$. The main specialties of lightweight concrete are its low density and low thermal conductivity light weight concrete is made by introducing air or gas into slurry composed of Portland cement and sand, so that when the mix sets and hardens uniform cellular structure is formed. Thus, it is a mixture of water, cement and finely fine aggregate. Mix fine powder to the slurry and it reacts with the calcium hydroxide present in it thus producing hydrogen gas. This hydrogen gas when contained in the slurry mix gives the cellular structure and thus makes the concrete lighter than the normal concrete. [1,2].

There are two types of lightweight concrete, the one using lightweight aggregate (Pumice stone) and the other water floating type. Second types using aluminum powder as an air entraining agent or any materials create bubbles inside the concrete mix. Also shows the importance of water/cement ratio as in first type of concrete it relates to the smoothness of the surface. [8].

Lightweight concrete which is known as (gas concrete), four additions of aluminum powder $(0.1,0.2,0.3,0.4) \%$ by weight of cement were used to produce gas concrete. Two different ways for curing, air and steam curing, were carried out using (5) $\mathrm{cm}$ cubes specimens, and noted the best ratio $(0.2) \%$ and the curing by steam best than curing by air. [9]

\section{Experimental Work}

\section{Materials}

\section{Cement}

Iraqi ordinary Portland cement manufactured by (tasloga factory trademark bazian) cement factory was used throughout this investigation. It was stored in a dry place (air-tight plastic 
containers) to reduce the effect of humidity and temperature. Table (1) shows the chemical and physical properties respectively [6].

Table (1)

Chemical composition of cement used in this investigation.

\begin{tabular}{|c||c||c|}
\hline $\begin{array}{c}\text { Abbreviation } \\
\text { of Oxide }\end{array}$ & $\begin{array}{c}\text { \% by } \\
\text { weight }\end{array}$ & $\begin{array}{c}\text { Limits of Iraqi } \\
\text { Specification } \\
\text { No.5/1984 }\end{array}$ \\
\hline \hline $\mathrm{SiO}_{2}$ & 21.95 & - \\
\hline \hline $\mathrm{CaO}$ & 63.32 & - \\
\hline \hline $\mathrm{MgO}$ & 1.48 & $\leq 5.0$ \\
\hline \hline $\mathrm{Fe}_{2} \mathrm{O}_{3}$ & 4.66 & - \\
\hline \hline $\mathrm{Al}_{2} \mathrm{O}_{3}$ & 3.76 & - \\
\hline \hline $\mathrm{SO}_{3}$ & 1.78 & $\leq 2.8$ \\
\hline $\begin{array}{c}\text { Loss on } \\
\text { Ignition }\end{array}$ & 0.83 & $\leq 4.0$ \\
\hline \hline $\begin{array}{c}\text { Insoluble } \\
\text { residue }\end{array}$ & 0.77 & $\leq 1.5$ \\
\hline $\begin{array}{c}\text { Lime saturation } \\
\text { factor }\end{array}$ & 0.96 & $0.66-1.02$ \\
\hline
\end{tabular}

\section{Fine Aggregate}

(AL-Ekadir in Karbala region) sand was used as fine aggregate. It was tested to determine the grading and other physical and chemical properties. Table (2) shows the sieve analysis of the used natural sand [7].

\section{Table (2)}

Grading of fine aggregate and requirements.

\begin{tabular}{|c||c||c||}
\hline $\begin{array}{c}\text { Sieve } \\
\text { Size } \\
(\mathbf{m m})\end{array}$ & $\begin{array}{c}\text { \% } \\
\text { Passing }\end{array}$ & $\begin{array}{c}\text { \% Passing according } \\
\text { to limits of I.O.S No. } \\
\mathbf{4 5 / 1 9 8 4}\end{array}$ \\
\hline 4.75 & - & $90-100$ \\
\hline \hline 2.36 & - & $85-100$ \\
\hline \hline 1.18 & 85 & $75-100$ \\
\hline \hline 0.60 & 70 & $60-79$ \\
\hline 0.30 & 25 & $12-40$ \\
\hline \hline 0.15 & 5 & $0-10$ \\
\hline
\end{tabular}

\section{Aluminum powder}

Used in this research Aluminum powder, and by trying show the ratio $2 \%$ is the best ratio from the weight of cement, the properties shown in Table (3).
Table (3)

Properties of Aluminum powder.

\begin{tabular}{||c||c||}
\hline Atomic .wt & 26.98 \\
\hline \hline Minimum assay & $93.0 \%$ \\
\hline $\begin{array}{c}\text { Maximum limits of } \\
\text { impurities }\end{array}$ & $\begin{array}{c}\text { Iron (Fe): } 0.5 \% \\
\text { Heavy metals } \\
\text { (as pb): } 0.03 \%\end{array}$ \\
\hline
\end{tabular}

\section{Cenosphere}

Used cenosphere in this project as a replacement of the weight of fine aggregate. Chemical and physical properties of micro ceramic material shown Table (4).

Table (4)

Chemical and physical properties of micro ceramic material.

\begin{tabular}{|c|c|}
\hline $\mathrm{SiO}_{2} \%$ by wt & $60-75$ \\
\hline $\mathrm{Al}_{2} \mathrm{O}_{3} \%$ by wt & $15-25$ \\
\hline Color & Grey off \\
\hline Bulk density & $0.38-0.42 \mathrm{~g} / \mathrm{cm} 3$ \\
\hline Real density & $0.65-0.75 \mathrm{~g} / \mathrm{cm} 3$ \\
\hline Particle size & $<0.5 \mathrm{~mm}$ \\
\hline Moister & $<0.5 \%$ \\
\hline Melting point & $1200-1400{ }^{\circ} \mathrm{C}$ \\
\hline
\end{tabular}

\section{Fiber glass}

Used in this research fiber glass to reinforced concrete by the weight of cement. The properties show in Table (5).

Table (5)

Properties of Fiber glass.

\begin{tabular}{||c||c||}
\hline Cross section & Rectangular \\
\hline \hline Fiber length & $6 \mathrm{~mm}: 10 \mathrm{~mm}$ \\
\hline \hline Tensile strength & $400 \mathrm{~N} / \mathrm{mm}^{2}$ \\
\hline Young modulues & $2600 \mathrm{~N} / \mathrm{mm}^{2}$ \\
\hline \hline Specific density & 0.91 \\
\hline
\end{tabular}

\section{Mixing and casting}

In this research used Cement, sand, Aluminum, and ceramic material called (cenosphere) to make type of concrete called (lightweight concrete). Many mixtures were made to try the best ratio of Aluminum powder that added to the cement to match the best reaction, so many samples were made and the best ratio was (2\%) from cement weight. Sand 
was replaced by micro ceramic material called (cenosphere) as a partial part gradual percent were $(25 \%, 50 \%, 75 \%$ and $100 \%)$ from the sand weight. Glass fiber was added to the previous mixtures by $(1 \%, 1.5 \%, 2 \%)$ percent from the cement weight to each mixture. Materials were mixed carefully, and $(50 \mathrm{ml})$ of water was added and cast in cubic molds of $(5 \times 5 \mathrm{~cm})$ dimensions. When samples were dried in the second day, samples were taken out and exposed to the air to be sure it become dry. Then, samples were exposed to water vapor after the maturity of samples for (15 hours). Then samples were dried in the air to be ready for test. Table (6) shows the proportions of mixtures.

Table (6)

Proportions of mixtures

\begin{tabular}{|c|c|c|c|c|c|c|}
\hline $\begin{array}{c}\text { Water } \\
\text { ml }\end{array}$ & $\begin{array}{c}\text { Aluminum } \\
\text { powder } \\
\text { (g) }\end{array}$ & $\begin{array}{c}\text { Cenospher } \\
\text { (g) }\end{array}$ & $\begin{array}{c}\text { Fiber glass } \\
\%\end{array}$ & $\begin{array}{c}\text { Fine } \\
\text { aggregate (g) }\end{array}$ & $\begin{array}{c}\text { Cement } \\
\text { (g) }\end{array}$ & Mix \\
\hline \multirow[t]{2}{*}{50} & 0 & 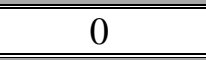 & $\overline{0}$ & 50 & 50 & pure \\
\hline & & & & & & $\overline{\mathbf{A}}$ \\
\hline \multirow[t]{2}{*}{50} & $\begin{array}{l}2 \% \\
2 \% \\
2 \%\end{array}$ & $\begin{array}{l}0 \\
0 \\
0\end{array}$ & $\begin{array}{c}1 \% \\
1.5 \% \\
2 \%\end{array}$ & $\begin{array}{l}50 \\
50 \\
50\end{array}$ & $\begin{array}{l}50 \\
50 \\
50\end{array}$ & $\begin{array}{l}1 \\
2 \\
3\end{array}$ \\
\hline & & & & & & B \\
\hline \multirow[t]{2}{*}{50} & $\begin{array}{l}2 \% \\
2 \% \\
2 \%\end{array}$ & $\begin{array}{l}12.5 \\
12.5 \\
12.5\end{array}$ & $\begin{array}{c}1 \% \\
1.5 \% \\
2 \%\end{array}$ & $\begin{array}{l}37.5 \\
37.5 \\
37.5\end{array}$ & $\begin{array}{l}50 \\
50 \\
50\end{array}$ & $\begin{array}{l}1 \\
2 \\
3\end{array}$ \\
\hline & & & & & & $\bar{C}$ \\
\hline \multirow[t]{2}{*}{50} & $\begin{array}{l}2 \% \\
2 \% \\
2 \%\end{array}$ & $\begin{array}{l}25 \\
25 \\
25\end{array}$ & $\begin{array}{c}1 \% \\
1.5 \% \\
2 \%\end{array}$ & $\begin{array}{l}25 \\
25 \\
25\end{array}$ & $\begin{array}{l}50 \\
50 \\
50\end{array}$ & $\begin{array}{l}1 \\
2 \\
3\end{array}$ \\
\hline & & & & & & D \\
\hline \multirow[t]{2}{*}{50} & $\begin{array}{l}2 \% \\
2 \% \\
2 \%\end{array}$ & $\begin{array}{l}37.5 \\
37.5 \\
37.5\end{array}$ & $\begin{array}{c}1 \% \\
1.5 \% \\
2 \%\end{array}$ & $\begin{array}{l}12.5 \\
12.5 \\
12.5\end{array}$ & $\begin{array}{l}50 \\
50 \\
50\end{array}$ & $\begin{array}{l}1 \\
2 \\
3\end{array}$ \\
\hline & & & & & & $\overline{\mathbf{E}}$ \\
\hline 50 & $\begin{array}{l}2 \% \\
2 \% \\
2 \%\end{array}$ & $\begin{array}{l}50 \\
50 \\
50\end{array}$ & $\begin{array}{c}1 \% \\
1.5 \% \\
2 \%\end{array}$ & $\begin{array}{l}0 \\
0 \\
0\end{array}$ & $\begin{array}{l}50 \\
50 \\
50\end{array}$ & $\begin{array}{l}1 \\
2 \\
3\end{array}$ \\
\hline
\end{tabular}

\section{RESULTS \& DISCUSSION}

\section{Density of concrete body}

The density of concrete body is very important measure to know the different between samples. Fig.(1) shows the density of samples as define in Table (7). The reason for this decreasing in density is due to the increase in air bubbles in the concrete which is formed by aluminum powder, and the ceramic powder instate fain aggregate. Table (8) show the density of samples contain fiberglass. 


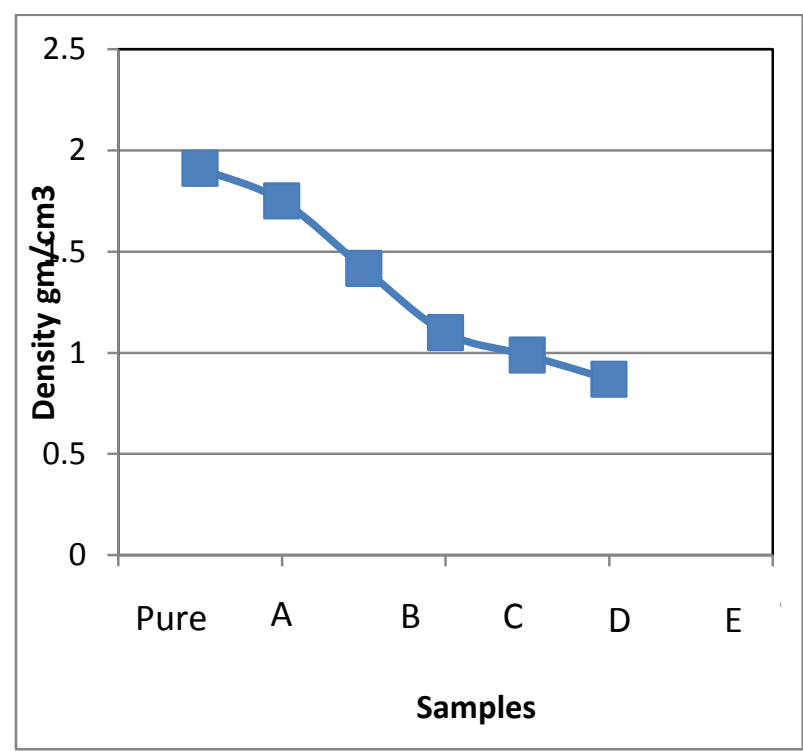

Fig.(1): Relation between density and samples.

Table (7)

Sample contain fiber glass.

\begin{tabular}{|c|c|c|c|}
\hline Sample & $\begin{array}{c}\text { Density } \\
\text { g/cm } \\
\text { F.G1\% }\end{array}$ & $\begin{array}{c}\text { Density } \\
\text { g/cm } \\
\text { FG1.5\% }\end{array}$ & $\begin{array}{c}\text { Density } \\
\text { g/cm } \\
\text { F.G2\% }\end{array}$ \\
\hline \hline Pure & 1.93 & 1.94 & 1.96 \\
\hline A & 1.77 & 1.79 & 1.81 \\
\hline B & 1.42 & 1.43 & 1.46 \\
\hline C & 1.1 & 1.13 & 1.16 \\
\hline D & 1 & 1.1 & 1.11 \\
\hline E & 0.870 & 0.87 & 0.90 \\
\hline
\end{tabular}

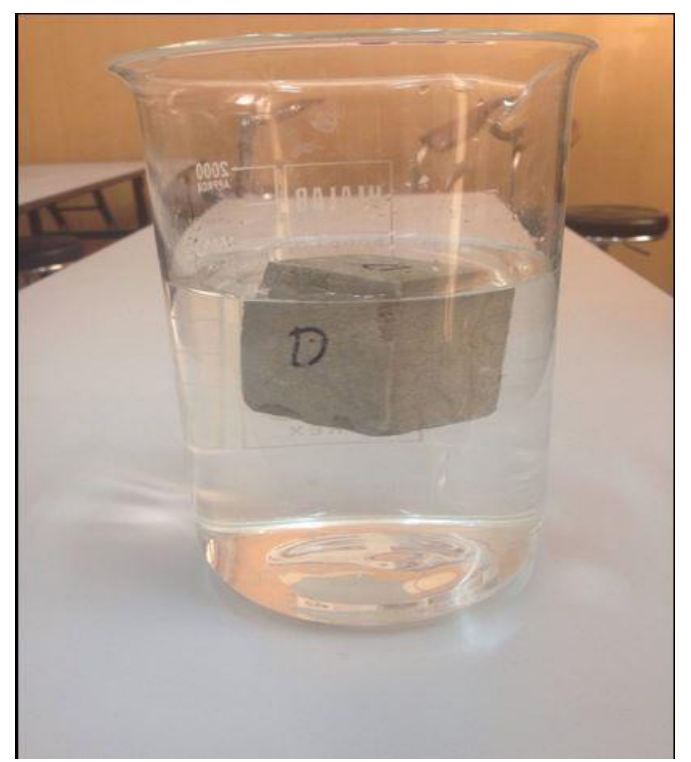

Fig.(2): Show the sample float on water.

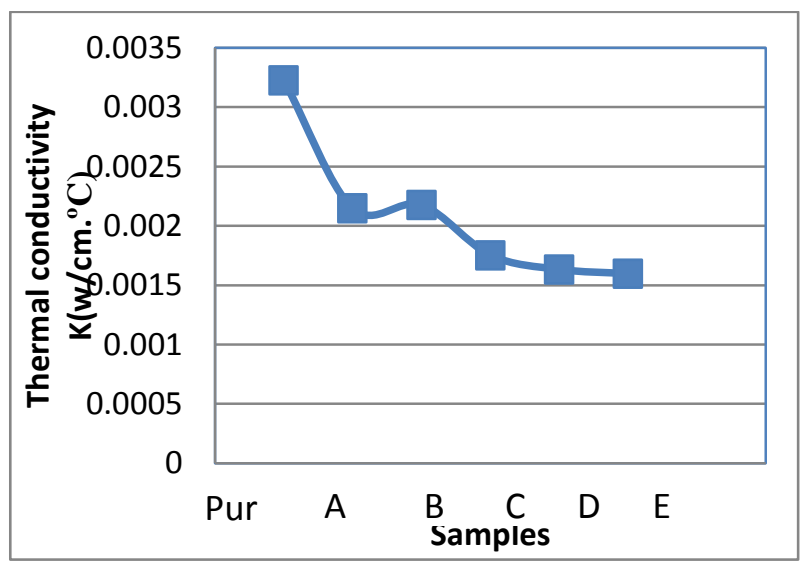

Fig.(3): Relation between thermal conductivity and Samples.

\section{Thermal Conductivity}

The thermal conductivity results shown in Table (8), where the reason for this decreasing in thermal conductivity is due to the presence of air bubbles that reduce heat transfer through the concrete body.

Table (8)

Thermal conductivity of sample.

\begin{tabular}{|c||c||c|c||c|c|}
\hline Sample & $\mathbf{T}_{\mathbf{A}}$ & $\mathbf{T}_{\mathbf{B}}$ & $\mathbf{T}_{\mathbf{C}}$ & $\begin{array}{c}\text { Thickness } \\
\text { (cm) }\end{array}$ & $\begin{array}{c}\text { Thermal } \\
\text { conductivity } \\
\mathbf{k}(\text { w/cm.C) }\end{array}$ \\
\hline \hline Pure & 31 & 41 & 41.5 & 13.63 & 0.003228 \\
\hline $\mathbf{A}$ & 36 & 45 & 45 & 8.31 & 0.002148 \\
\hline \hline B & 33 & 44 & 45 & 10.5 & 0.002176 \\
\hline C & 39 & 48 & 48 & 6.83 & 0.001753 \\
\hline D & 35 & 45 & 45 & 7.9 & 0.001633 \\
\hline E & 34 & 45 & 45 & 7.8 & 0.001597 \\
\hline
\end{tabular}

\section{Compressive strength test}

Compressive strength is the most important property of concrete since the first consideration in structural design is that the structural elements must be capable of carrying the imposed loads. Fig.(4) show the increase in compressive strength by increasing the bubbles by aluminum powder and ceramic powder, the reason is the curing time of samples, by fix the time of curing by steam, the samples have porous completed the curing faster the sample don't have porous, thus obtain compressive strength in light concrete higher than normal concrete. 


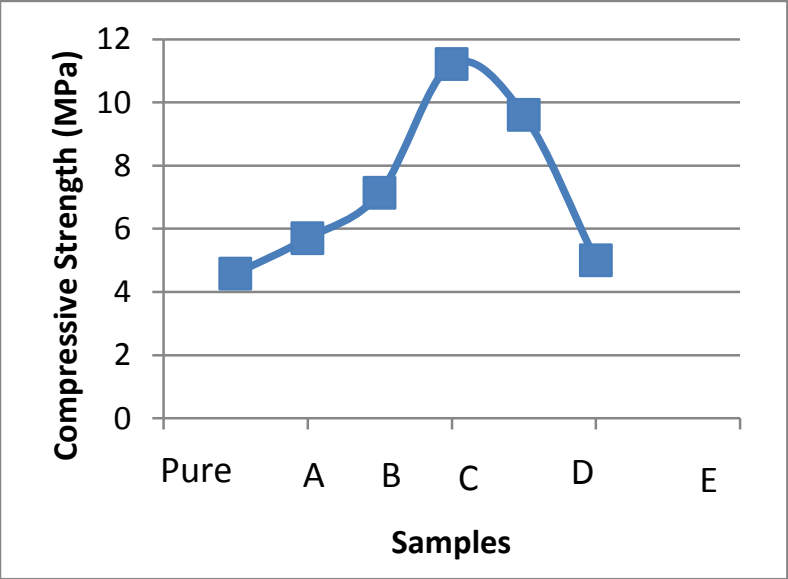

Fig.(4):Relation between compressive strength and samples.

Table (9)

Compressive strength with Fiberglass.

\begin{tabular}{|c||c|c||c||}
\hline \multirow{3}{*}{ Samples } & $\begin{array}{c}\text { Comp. } \\
\text { MPa } \\
\text { F.G 1\% }\end{array}$ & $\begin{array}{c}\text { Comp. } \\
\text { MPa } \\
\text { FG } \\
\mathbf{1 . 5 \%}\end{array}$ & $\begin{array}{c}\text { Comp. } \\
\text { MPa } \\
\text { F.G 2\% }\end{array}$ \\
\hline \hline Pure & 8.3 & 8.5 & 8.2 \\
\hline \hline A & 11.5 & 15.9 & 14.3 \\
\hline \hline B & 11.14 & 12.4 & 11.3 \\
\hline \hline C & 15.3 & 17.1 & 14.9 \\
\hline \hline D & 9.9 & 10.2 & 10.13 \\
\hline E & 8.8 & 9.4 & 9 \\
\hline
\end{tabular}

\section{Tensile strength test}

The tensile strength its less important property for concrete and much lower than compressive strength because the inherent pores and gaps in the concrete which as micro cracking which concentrating the stresses and give catastrophically failure, so the samples reinforced by fiberglass to increase the resistance to tensile. Fig.(5) show the relation between samples and tensile, and the Table (10) show the tensile strength with fiberglass.

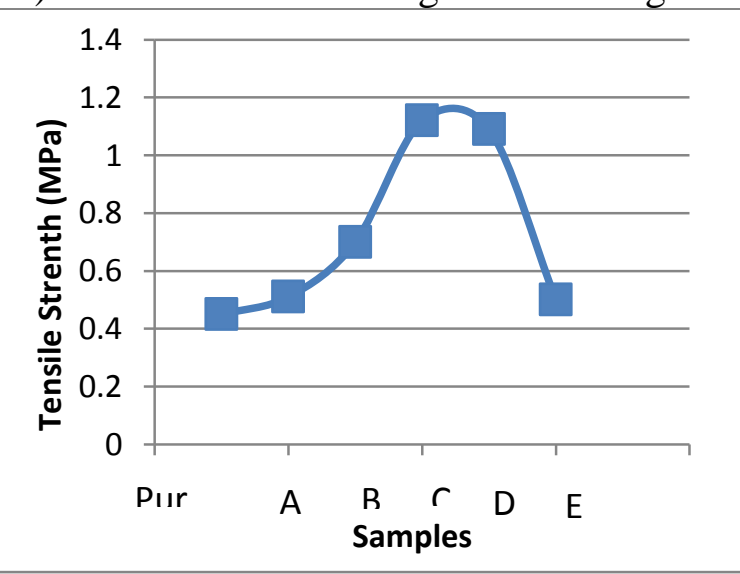

Fig.(5): Relation between tensile strength and samples.
Table (10)

Tensile strength with fiberglass.

\begin{tabular}{|c||c||c||c||}
\hline \multirow{4}{*}{ Sample } & $\begin{array}{c}\text { Tensile } \\
\text { Strength. } \\
\text { MPa } \\
\text { F.G } \\
\mathbf{1 \%}\end{array}$ & $\begin{array}{c}\text { Tensile } \\
\text { Strength. } \\
\text { MPa F.G } \\
\mathbf{1 . 5 \%}\end{array}$ & $\begin{array}{c}\text { Tensile } \\
\text { Strength.MPa } \\
\text { F.G } \\
\mathbf{2 \%}\end{array}$ \\
\hline \hline Pure & 0.81 & 0.84 & 0.80 \\
\hline A & 1.2 & 1.6 & 1.41 \\
\hline B & 1.11 & 1.25 & 1.12 \\
\hline C & 1.51 & 1.9 & 1.70 \\
\hline D & 1.18 & 1.31 & 1.2 \\
\hline E & 0.9 & 0.95 & 0.91 \\
\hline
\end{tabular}

\section{Change in the high of sample}

We observed from the samples that have been made a change in the height of samples when adding the variables in the concrete mix, because other fixed-dimensional because of the presence of mold. Table (11) show the different high in samples.

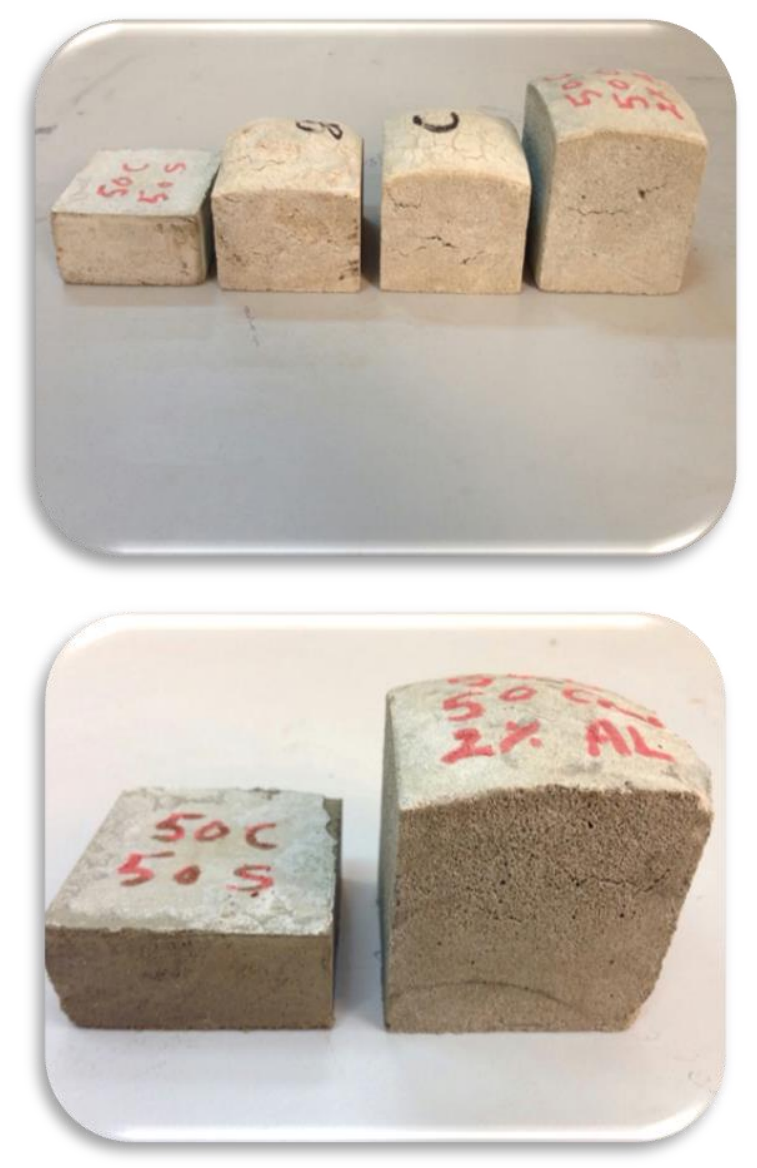

Fig.(6): show the high of samples. 
Table (11)

Different high in samples.

\begin{tabular}{|c||c|}
\hline Samples & High $(\mathrm{mm})$ \\
\hline \hline Pure & 25.26 \\
\hline A & 30.2 \\
\hline B & 35.9 \\
\hline \hline C & 40.8 \\
\hline D & 43.12 \\
\hline E & 57.51 \\
\hline
\end{tabular}

6. SEM

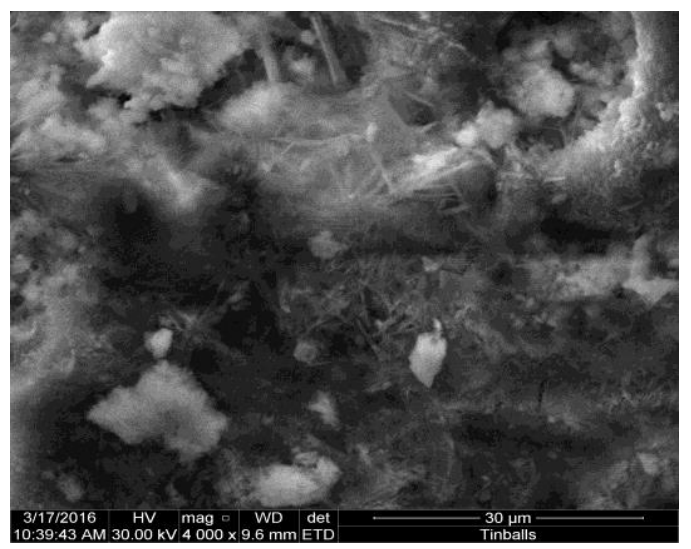

Fig.(7): SEM (reference concrete).

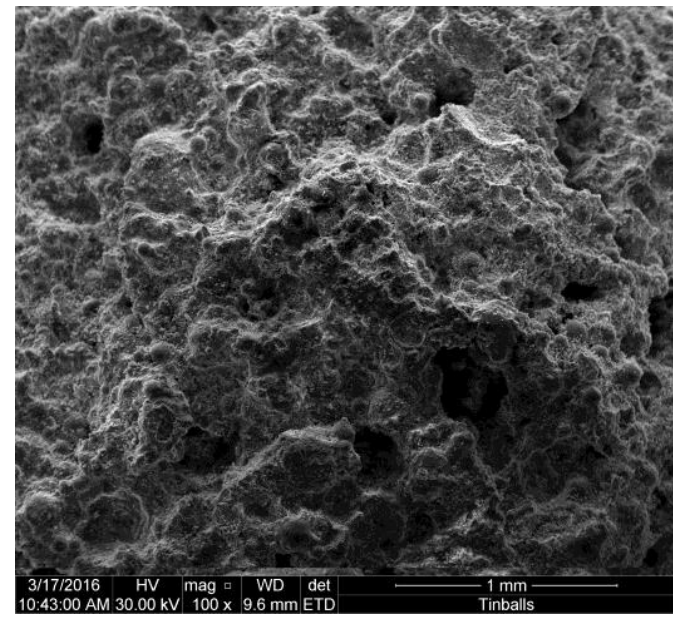

Fig.(8): SEM (show bubbles with cenoshoere inside concrete body).

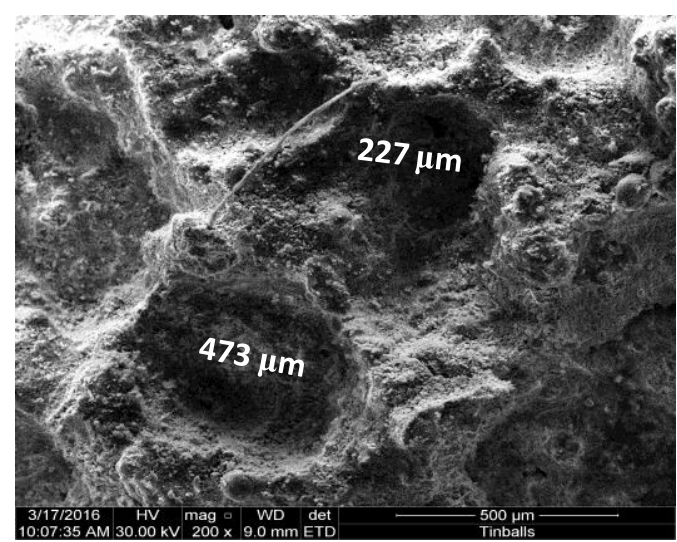

Fig.(9): SEM (show diameter of buubles).

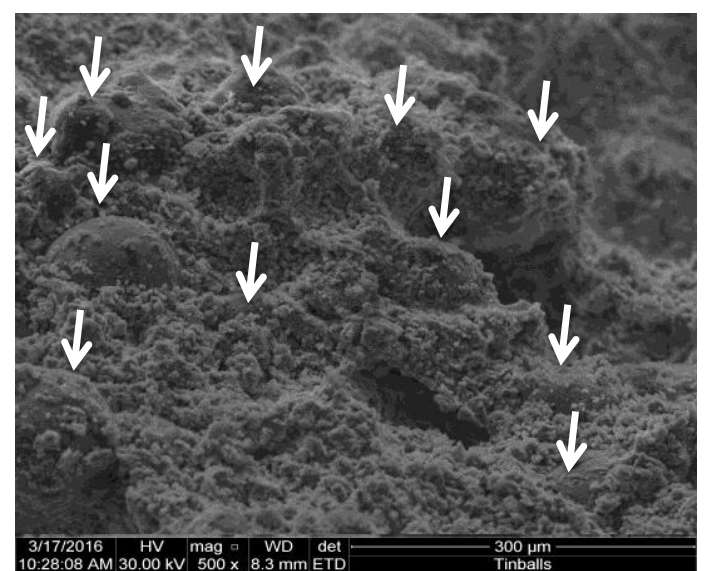

Fig.(10): SEM (show cenosphere in concrete body).

Noted from the SEM image, the Fig.(7) reference sample shows the needle of cement produce from the hydration of cement with water. Fig.(8) show the bubbles (entire gas) that produce from reactive aluminum powder with cement and show also good distribution of bubbles. Also show from Fig.(9) the dimeter of bubbles. Fig.(10) show distribution of cenoshpere inside the concrete body.

\section{Conclusion}

Conclusion from this study:-

1. After the attempt to add several ratios of aluminum powder to the concrete mix, to get the highest percentage of voids (bubbles) inside the body of the concrete is $(2 \%)$ of the weight of cement, so this ratio has been circulating on all mixes.

2. An increase in the mechanical properties (compression and tensile) when add fiber glass. The best ratio (1.5\%) of the weight of cement, because it was noted that the increase added more than this percentage decreases mechanical properties.

3. Replacing part of the sand with cenosphere to get a decrease in the weight of the samples, so the best mechanical properties at ratio $(50 \%)$ cenosphere. The lower thermal isolation and less density at ratio $(100 \%)$ cenosphere.

4. Sample $C$ recorded the highest mechanical properties, also possesses good thermal isolation of density compared with the reference sample. 


\section{Reference:}

[1] Neville, A.M., "Properties of concrete", London, fourth edition, 2005.

[2] Orchard, F, D "Concrete Technology" Vol.1, fourth edition, 1979.

[3] Chau, and Newmen, "Advanced concrete technology", 2003.

[4] Olin, Etal, "Construction, method and properties", USA, 1998.

[5] ACI-116R-85 "Cement and Concrete Terminology", ACI Manual of Concrete practice, part 2, Detroit, Michigan 1989.

[6] Iraqi specification (No.5) 1984 for Cement.

[7] Iraqi specification (No.45) 1984 for aggregate.

[8] Dhawal Desai, "development of light weight concrete", Indian Institute of Technology Bombay, des. 2011.

[9] Prof. Dr. Mohammed Mosleh Salman, "Empirical formulas for estimation of Some Physical Properties Of gas concrete Produced By Adding Aluminum Powder", Al-Mustansiriya University_Baghdad- Iraq, Journal of Engineering and Development, Vol. 14, No. 4, December, 2010 ISSN 1813-7822.

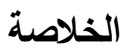

البحث بدرس تحضير خرسانة خفيفة الوزن بالطريقة

الكيميائية. أضافة (r\%) من مسحوق الالمنيوم من وزن بـن

الاسمنت للحصول على فقاعات داخل الخلطة الخرسانية.

كذللك أستبدال الركام الناعم بمسحوق سيراميكي فراغي يسمى لاسيى

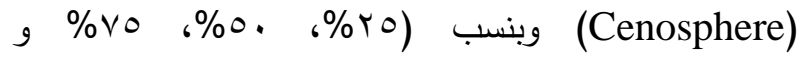

م . . . . من وزن الركام. كذلك تم أضافة الألياف الزجاجية

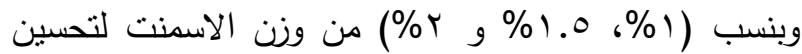

الخصائص الميكانيكية للعينات. أظهرت النتائج زيادة في قوة

الأنضغاط والثد بزيادة الـ (Cenosphere) بدلا عن الركام

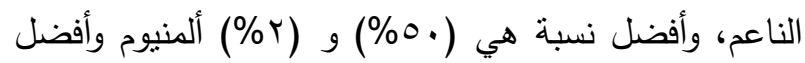

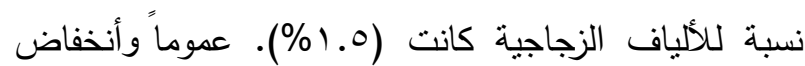

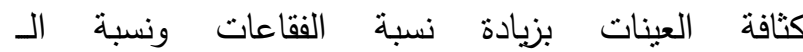
بدلا عن الركام الناعم، كانت الكثافة (Cenosphere)

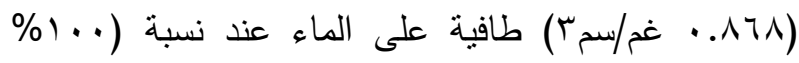
Cenosphere الالمنيوم وأستبدال مسحوق السيراميك (Cenosphere) بدلا لـانه
عن الركام الناعم. لوحظ أيضا زيادة ارتفاع العينات من

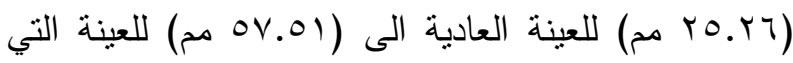
تحتوي (·) (Cenosphere \%) و (r\%) مسحوق الالمنيوم. 